Journal of Southeast Asian

Volume 15

Issue 2 Voices from the Field: Centering

Southeast Asian Americans through Policy,

Article 2

Practice, and Activism

2020

\title{
An Empirical Exploration of Southeast Asian-Americans in Education Research: A Qualitative Meta-Analysis
}

Peter T. Keo

Stanford University, peterkeo@stanford.edu

Follow this and additional works at: https://docs.lib.purdue.edu/jsaaea

Part of the Bilingual, Multilingual, and Multicultural Education Commons

\section{Recommended Citation}

Keo, Peter T. (2020) "An Empirical Exploration of Southeast Asian-Americans in Education Research: A Qualitative Meta-Analysis," Journal of Southeast Asian American Education and Advancement: Vol. 15 : Iss. 2, Article 2.

DOI: $10.7771 / 2153-8999.1210$

Available at: https://docs.lib.purdue.edu/jsaaea/vol15/iss2/2

This document has been made available through Purdue e-Pubs, a service of the Purdue University Libraries.

Please contact epubs@purdue.edu for additional information.

This is an Open Access journal. This means that it uses a funding model that does not charge readers or their institutions for access. Readers may freely read, download, copy, distribute, print, search, or link to the full texts of articles. This journal is covered under the CC BY-NC-ND license. 


\title{
JSAAEA Journal of Southeast Asian American
Education and Advancement
}

Vol. 15 Iss. 2 Special Issue (2020) www.JSAAEA.org

\section{An Empirical Exploration of Southeast Asian Americans in Education Research: A Qualitative Meta-Analysis}

\author{
Peter T. Keo \\ Stanford University
}

\begin{abstract}
This research examined how Southeast Asian-Americans are treated in leading K-12 and higher education research. A qualitative meta-analysis was conducted using secondary data sources. I analyzed 1,192 pages of text from 151 peer-reviewed academic articles in six K-12 and higher education journals. In a span of 10 years (2007-2016), only four of the 151 articles (2.6\%) reviewed specifically addressed in whole or in part Southeast Asian-Americans - one of the most disadvantaged ethnic minority groups in America. Findings demonstrated that aggregating racial data for Asian-Americans silences under-represented Southeast Asian-Americans, suggesting that the continued fight for racial equality in educational research for Southeast AsianAmericans requires more attention at the most basic level.
\end{abstract}

Keywords: K-12, Higher Education, Asian-Americans, Southeast Asian-Americans, Racial Equality

\section{Introduction}

The main argument for this study is: Southeast Asian-Americans are silenced in leading K-12 and higher education research when Asian-Americans are aggregated by race, as studies tend to ignore the rich political, economic, social, migratory, and cultural factors that shape these individuals and the "Asian" communities from which they come. This phenomenon was evident in a qualitative meta-analysis which had been conducted for the present study using secondary data sources. In addition to Southeast Asian-Americans, I quantitatively analyzed data across large racial minority groups in the United States (i.e., African Americans/Blacks, Hispanics/Latinos, Asians, and Natives) but that information will not be presented due to space constraint.

Stacey Lee (2006) explored how the educational opportunities, experiences, and achievements of Asian-Americans are shaped by social class, ethnicity, generation, and gender. She addressed the potential danger in applying the Asian-American pan-ethnic category, noting

\footnotetext{
(c)

SDRERIIGHISRESERNEDR Readers are free to copy, display, and distribute this article, as long as the work is attributed to the author(s) and the Journal of Southeast Asian American Education \& Advancement, it is distributed for non-commercial purposes only, and no alteration or transformation is made in the work. More details of this Creative Commons license are available at http://creativecommons.org/licenses/by-nc-nd/3.0/. All other uses must be approved by the author(s) or JSAAEA. Journal of Southeast Asian American Education \& Advancement, Vol. 15. Iss. 2. (2020) ISSN: 2153-8999
} 
that "not only does it underestimate the differences and hybridities among Asians, but it may also inadvertently support the racist discourse that constructs Asians as a homogenous group, that implies that Asians are 'all alike' and conform to 'types"' (p. 17, as cited in Lowe, 1996, p. 71). Lee argued that to avoid homogenizing Asian-American students, educators and policymakers need to examine how varying identities intersect to inform their experiences in order to uncover differences between and within ethnic groups. Thus, the intersection of social class, ethnicity, gender, and generation is likely to "create differences in circumstances and opportunities that affect the social and academic experiences of Asian-American students" (p. 18).

Referring to Ong's (1999) study on non-White immigrants, research found that wealthy Chinese immigrants were ideologically whitened because Whiteness and middle class-ness are often conflated. An example of ideological Whitening was the standard conception that AsianAmericans were often viewed as highly successful model minorities. Conversely, lower-income Southeast Asian-Americans were often ideologically Blackened in the dominant discourse given the high rates of poverty among Cambodian, Hmong, Laotian, and other subgroups. This is an example of how different identities intersect to shape the experiences of Asian-American students.

Poon and colleagues (2016) attempted to deconstruct the model minority myth in the context of anti-blackness and White supremacy. Their study critiqued extant research that examined Asian-Americans (in addition to Pacific Islanders) between the bifurcation of the model minority myth and the counter-model minority myth. Their central argument was that, "Simply defining the [myth] as a stereotype about Asian-Americans without recognizing its insidious implications for disciplining and shaming other people of color deflects attention away from how the myth is integral to a project of maintaining White supremacy" (p. 489). They further noted that a critical flaw in examining low educational attainment among marginalized Southeast AsianAmericans, for example, to counter the "stereotype and aggregate statistics of high achievement" among this subpopulation, is that it "essentializes ... ethnic groups based on educational achievement [and that] overlook[s] the dynamism and fluidity of diverse lived experiences" (pp. 488-489). They also argued that "merely negating, contesting, and complicating the hegemonic framing of Asian-Americans in higher education often unintentionally reinforced this oppressive framing and other hegemonic frames" (p. 490). The authors suggested that scholarship ought to focus on the varied and complex experiences and voices of Asian-Americans to contribute "critical deconstructions of systemic White dominance."

However, what is not entirely clear from extant research on Asian-Americans is how and whether marginalized, low-income Asian-Americans have become empirical collateral damage to a broader political and cultural war that has systemically and systematically whitenized and blackenized (Ong, 1999) Asian-Americans either as stories of success or failures. It is curious whether extant social science research has played into this conceptualization, which research reveals could be a response to oppressive, racist, and hegemonic frames (Stacey Lee, 2006; Lowe, 1996; Poon et al., 2016).

\section{Purpose of the Study}

I explore how Southeast Asian-Americans are treated in leading K-12 and higher education research (see Chou, 2015; Ngo \& Lee, 2007; Poon et al., 2016; Sharon Lee, 2006; Song, 2004; Stacey Lee, 2006; Tuan, 1999; Wu, 2003). Specifically, I am interested in determining how underrepresented Asian-American subgroups (i.e., Cambodian, Hmong, Laotian, and Vietnamese) are viewed in research that aggregates Asian-American data. Southeast Asian-Americans are some of 
the most under-represented populations in the United States, according to recent U.S. Census data. This is particularly evident when we account for the intersection of race, ethnicity, class, and gender.

\section{Analytic Framework}

This article uses Critical Race Theory (CRT) as a framework. CRT enables scholars to interrogate the extent to which race determines varying outcomes for marginalized communities in the law, public policies, employment, housing, and K-12 and higher education. CRT engages in theoretical and empirical sensemaking by bringing into the analysis issues related to economics, history, context, and group- and self-interest. Thus, scholars can engage in deeper, more complex discourses and analyses around race relations in America, particularly as they pertain to equity, access, and opportunity (Delgado \& Stefancic, 2012, see Ladson-Billings, 2011).

In Critical Race Theory: An Introduction, Richard Delgado and Jean Stefancic (2012, pp. 7-10) lay out major tenets of CRT, noting that not every tenet may be applicable to every scholar, but many would agree on a few propositions:

1. Social construction holds that race and races are products of social thought and relations. Not objective, inherent, or fixed, they correspond to no biological or genetic reality; rather, races are categories that society invents, manipulates, and retires when convenient.

2. Differential racialization draws attention to the ways the dominant society racializes different minority groups at different times, in response to shifting needs such as the labor market.

3. Voice-of-color thesis holds that because of different histories and experiences with oppression, ethnic minority writers and thinkers may be able to communicate to their counterparts matters that they are unlikely to know. Thus, minority status brings with it a presumed competence to speak about race and racism.

Differential racialization frame enables scholars to analyze data and investigate the treatment of Asian-Americans in response to contemporary social challenges in the marketplace. Regarding Asian-Americans as a monolithic group, Delgado and Stefancic noted that a recently arrived Hmong (i.e., an ethnic minority subgroup from Southeast Asia) may have a rural background in the homeland unfamiliar with mercantile life, whereas a fourth-generation Chinese (with a father who is a university professor and mother who operates a business) is likely to have a different lived experience compared to the Hmong person. The implication here is that the multiple and varied cultural and linguistic differences within the Asian-American community requires an equally nuanced understanding of their epistemological orientation. For this study, however, I use the voice-of-color thesis which asserts that ethnic minority writers and thinkers may be able to communicate to their counterparts matters that they are unlikely to know, given their different histories and experiences with oppression. Thus, the Southeast Asian-American minority status brings with it a presumed competence to speak about race and racism in the context of a monolithic "Asian" America. This thesis is an attempt to provide counter-narratives to the model minority myth. 


\section{Method}

\section{Data Source}

The purpose of utilizing meta-analysis is to examine a particular phenomenon beyond one study (Finfgeld, 2003), and to systematically review the results of many studies (Normand, 1999). Because I was interested in a thorough and systematic review of extant literature, I decided to employ a qualitative meta-analysis instead of a critical literature review which is an unsystematic discussion of the literature. A systematic review was helpful in working through and reducing the number of literatures selected for final analysis, which could have been overwhelming without a more systematic approach. Therefore, this study conducted a qualitative meta-analysis of secondary data sources, meaning articles that had been previously published by other scholars in leading peer-reviewed journals. Though certainly trained to do so, I decided not to conduct a quantitative meta-analysis because studies that cover this topic are extremely limited. Therefore, it would have been empirically and statistically impossible to estimate the summary effect sizes of different studies.

Finfgeld (2003) described qualitative meta-analysis as "a new and integrative interpretation of findings that is more substantive than those resulting from individual investigations" (p. 894, as cited in Timulak, 2009, 591). Timulak (2009) noted that there are typically two goals of qualitative meta-analysis: "(a) to provide a more comprehensive description of a phenomenon researched by a group of studies, including its ambiguities and differences found in primary studies, and (b) to provide an assessment of the influence of the method of investigation on findings" (p. 592). Because I was interested in treating the findings as data for the meta-analysis (see Timulak, 2007), I decided to undertake the first goal, which was to review extant findings in order to describe "a phenomenon researched by a group of studies."

\section{Database Searches}

I analyzed 1,192 pages of peer-reviewed academic journal articles in six K-12 and higher education journals (see Table 1). Specifically, I conducted searches in:

1. American Educational Research Journal

2. Review of Educational Research

3. Review of Research in Education

4. Equity \& Excellence in Education

5. The Journal of Higher Education

6. Research in Higher Education

Table 1. Peer-reviewed journal articles reviewed.

\begin{tabular}{ll}
\hline Journal & $N$ \\
\hline American Educational Research Journal & 33 \\
Review of Educational Research & 22 \\
Review of Research in Education & 17 \\
Equity \& Excellence in Education & 33 \\
The Journal of Higher Education & 22 \\
Research in Higher Education & 24 \\
\hline
\end{tabular}


These journals were selected based on popularity using an online ranking system (SJR: Scientific Journal Rankings - SCImago). They were also selected given their familiarity among researchers who conduct empirical studies on K-12 and higher education. First, I browsed all titles and abstracts of every article, spanning a ten-year period (2007-2016). The ERIC, EBSCOhost Academic Search Premiere, and JSTOR databases were searched. Second, in reviewing titles and abstracts, I finally decided to select 151 articles for this study's analysis that focused invariably on the following topics: racial equity; academic achievement; Asian-Americans; Southeast AsianAmericans; Pacific Islanders; Native Hawaiians; Native Americans; African Americans/Blacks; and Hispanics/Latinos.

\section{Inclusion Criteria}

In the six refereed journals, I decided to refine the search by selecting 151 articles that met specific inclusion criteria:

- Empirical studies that reported findings on racial equity and academic achievement for large racial minority groups in the United States (i.e., African Americans/Blacks, Hispanics/Latinos, Asians, and Natives), particularly in the context of grades K-12 and higher education.

- Findings that were seemingly valid based on the study's research design, data, sample, and analytic methods.

- Studies that employed both quantitative and qualitative research methods.

- Empirical studies that reported findings on racial minority male and/or female students.

- Journal articles that were published between 2007 and 2016 (a 10-year period).

I excluded articles about rural Whites, given the article's focus on large racial minority groups in the context of grades K-12 and higher education. I also excluded articles that were deemed "race neutral." Specifically, articles that addressed the issue of "race" without necessarily and explicitly referring to specific racial/ethnic groups for analysis. For example, I left out articles that examined race and ethnicity as the point of analysis but did not refer explicitly to African Americans/Blacks or Hispanics/Latinos.

\section{Coding}

I downloaded each of the 151 articles for analysis. In each published article, I first conducted a search for three keywords - race, equity, and achievement - into the search window. Second, I scanned each publication to determine the extent to which "Asian-Americans" was included in the research and did a search for one additional keyword: Southeast Asian-American.

I copied text from the 151 journal articles (PDFs) and pasted the text into one large Microsoft Word document. I pasted text only from the "Discussion" and "Implications" sections (1,192 pages) for analysis. I employed Miles and Huberman (1994) for textual and categorical analysis. Specifically, in two rounds, I read the "Discussion" and "Implications" sections. I went through the text, highlighted passages, and applied three categorical codewords: a) AsianAmerican aggregation: This codeword captured the extent to which the author(s) aggregated 
Asian-Americans, viewing them as one racial minority group; b) Asian-American equity: This codeword captured explicit attempts to dismantle false myths about the Asian-American community; and c) Southeast Asian-American disaggregated: This codeword captured publications that made explicit attempts to highlight Southeast Asian-Americans in creating counter-narratives to the stereotypes. After the coding process, I did a thorough and repetitive reading of the code reports. That led me to Critical Race Theory's differential racialization (Bell, 2005; Delgado and Stefancic, 2012), which draws attention to the way in which the dominant society racializes different minority groups at different times.

\section{Results}

Only four of the 151 articles (2.6\%) reviewed in the six leading K-12 and higher education journals, that fit within the selection criteria, specifically addressed in whole or in part Southeast Asian-Americans, arguably one of the most marginalized populations in the United States measured by high school graduation and poverty rates. One article $(.7 \%)$ provided a critique of the model minority myth within the constructs of anti-blackness and White supremacy (the lead author was an Asian-American); and 12 articles (7.9\%) altogether attempted to dispel the model minority myth, whether examining Asian-Americans as a broad racial group or Southeast Asian-Americans more specifically. This finding demonstrates a serious disproportionality in terms of publication coverage (by both researchers and leading peer-reviewed education journals) for Asian-Americans either as a broad racial group or Southeast Asian-Americans as under-represented subgroups.

In reviewing the 151 peer-reviewed journal articles for analysis, two major themes had emerged from the data: a) Researchers aggregated Asian-American data; and b) Researchers disaggregated Asian-American data. Subsumed under the first theme was: assuming broadly that all Asian-Americans are the same; under the second theme was: creating counter-narratives through Southeast Asian-American stories. I highlighted patterns across the peer-reviewed publications, identifying how Southeast Asian-Americans were "treated" by researchers in the academy.

\section{Researchers Aggregated Asian-American Data}

\section{Assuming Broadly That All Asian-Americans Are the Same}

An overwhelmingly large majority (97\%) of the publications treated Asian-Americans as a monolithic group. Researchers often accounted for the nearly 25 ethnicities as one racial group under the larger "Asian" umbrella category, systematically ignoring complex lived realities, languages, cultures, and stories of entry into the United States. In the context of Southeast AsianAmericans and academic achievement, for example, one study noted, "[T] he lumping of various Asian ethnic groups into the Asian-American category hides variation in academic attainment and achievement across groups." Another study that conducted a critical review of Asian-American literature, noted:

Representations of Asian-Americans are highly political and manufactured to support a stance, as in the case of affirmative action, and distract us from understanding the diversity of Asian-American experiences ... For those who 
embrace a model minority image, it is easy to disregard Asian-American students ... Asian-Americans should not be excluded based on statistics alone.

In terms of data aggregation of Asian-Americans, there were two trends. First, a small number of researchers attempted to challenge mainstream views of the model minority myth by presenting data that were also aggregated. For example, one researcher noted, "The model minority was frequently used to castigate black and Latina/o communities ... [fostering] intergroup antagonism where racial minorities battle each other instead of fighting against systemic racism." The same researcher also found that "racism is framed as a black/white issue (sometimes White/Latina/o), and the racialization of Asian-Americans is not considered even among racially progressive white men" [italics emphasized]. The trend across publications noted that AsianAmericans were often viewed as "intellectually superior," "high performing (especially in math)," "honorary whites," and "not true racial minorities." It was also noted that these perspectives, though broad and generalized, live at the center of the model minority myth, which has sustained a degree of popularity among mainstream researchers in the academy.

Researchers generally interrogated the model minority myth in higher education and the workforce. For example, another study addressed how Asian-Americans experienced "discrimination" in accessing support at the senior level administrative positions in higher education. The author noted, "At the senior levels of administration, the pipeline analysis indicates a significant problem that has gone essentially unrecognized by the higher education community, particularly with Asian-Americans, which often are not included in the net of intervention or support methods." That is, Asian-Americans were not supported in academic administration.

With regard to data aggregation, the second trend unearthed how K-12 and higher education researchers explicitly played into the model minority myth, and some publications viewed Asian-Americans "as honorary whites" and pitted Asian-Americans against other racial minority groups. Researchers overwhelmingly viewed Asian-Americans as "high performing" which invariably supported the notion that they were "intellectually superior" especially in math. For example, in a higher education article that addressed the issue of "access without equity," words built into the title, in which the lead author was a White woman at a top R1 research institution, the authors claimed, "Academic preparation among Black and Latino students has improved across the board, but similar rates of improvement among White and Asian students on some indicators paired with institutions' increasing reliance on SAT scores help to preserve institutional stratification by race," going on to note, "we do a disservice to current Black and Latino students by not striving to accelerate their qualifications relative to White and Asian students on criteria that affect enrollment." In this instance, researchers have pitted "Whites and Asians" against "African Americans/Blacks and Hispanics/Latinos." Comparing "AsianAmericans" to "African Americans/Blacks and Hispanics/Latinos" was done through the lens of racial stratification, a sociological frame that draws broad conclusions which has the potential to erase under-represented populations like Southeast Asian-Americans.

In other studies, researchers addressed the importance of "disaggregation" without naming it as such. However, in doing so, they inadvertently pitted Asian subgroups to other underrepresented racial groups. For example, one publication noted, "[S]tudies show that certain immigrant minority groups (e.g., Chinese Americans, Korean Americans, and South AsianAmericans) fare better academically than many other racial and ethnic groups (e.g., African Americans, Mexican Americans, and Native Americans)," going on to note, "Because the former groups outperform students who are the descendants of slaves or colonized peoples, the ensuing 
logic is that there must be something either group specific or cultural that explains these differences."

Another study that examined the educational experiences of Chicana/Latina students noted, in referring to an interviewee's response, "She described being self-conscious [and] felt that she would not perform on the same level as her [Asian-American] peers, who she perceived were 'smarter' than her." This study pits Asians against, in this case, a Chicana/Latina student. The lead author of this study works for a higher education institution within close proximity to one of the largest low-income Southeast Asian-American populations in the United States.

Another K-12 publication reinforced the notion that Asians were "high achieving" and "intellectually superior." For example, one study that aggregated Asian-Americans indicated, "Asian-American students attend more prestigious schools than Whites, while results for AfricanAmerican and Latino students show that they attend schools with less institutional selectivity than Whites," going on to note, "Asian-American students attend significantly more prestigious colleges than White students, net of other variables." These arguments tend to be broad and seek to substantiate affirmative action claims.

However, Asian-American researchers, though to a lesser degree, also used aggregated data to pit Asians to other racial minority groups. One study authored by an Asian-American noted, "In terms of racial/ethnic differences, Native Americans and African Americans dropped out at the highest rates ... Asian-Americans (69.15\%) and Whites (59.30\%) had higher rates of persistence than other ethnic groups." Again, in this instance, when data were aggregated, researchers-including Asian-Americans-tended to equate Asians with Whites, and then proceeded to wedge them against other under-represented ethnic minority groups.

Authors tended to "justify" an apparent negligence by qualifying their findings, as such: "[G]iven the considerable heterogeneity within the White and Asian-American categories (and the imperfection of the categories), our findings should not be interpreted to structure policy or programs that may affect these groups' opportunities, writ large." However, publications under investigation failed to explain the "considerable heterogeneity" that exists within White and AsianAmerican subgroups. Naming "heterogeneity" without an explanation lacks criticality, in which scholars critically analyze subgroups at the intersection of ethnicity, class, gender, power, and privilege. The absence of criticality could lend itself to some level of harmful stereotyping.

There was also a trend which assumed that Asian-Americans excelled in math. For example, one study noted: "[T]he most important problem in mathematics education is the gap in performance between middle- and lower-class students and between White and Asian-American students and African American, Hispanic, and Native American students." Other studies were more egregiously explicit in their findings. For example, another study had mentioned the "distress" the author felt in examining "deficiencies" across racial groups, with Whites and Asians on one side, and African Americans/Blacks and Hispanics/Latinos on the other. He noted:

Blacks and Hispanics begin the remedial math sequence with substantially greater average deficiencies than do Whites and Asians ... Black and Hispanic remedial math students enroll disproportionately in arithmetic, while Whites and Asians enroll disproportionately in intermediate algebra or geometry ... This finding is distressing in that it reveals that the well-documented racial stratification in math achievement in the United States persists even into the lowest echelon of postsecondary math (remedial math) and contributes to racial disparities in outcomes ... This indicates that ... mathematics remediation appears to be relatively 
equally effective across racial lines. While more than one-quarter of White remedial math students and one-third of Asians attain college-level math skill within six years, only one-fifth of Hispanic and one-ninth of Black students do so.

The studies above relied heavily on data that were aggregated by Asian-American subgroups. In other words, researchers analyzed available statistical data that traditionally lumped all Asian subgroups under one broad category. It is curious whether findings would have merit if two things had occurred: a) federal datasets used for these types of studies disaggregated data by ethnic subgroups (e.g., Southeast Asian-American and not Asian-American), and b) researchers intentionally and purposefully investigated outcomes in the context of recognizing that AsianAmericans have seldom benefitted from hierarchies of power (Stacey Lee, 2006)?

\section{Researchers Disaggregated Asian-American Data}

\section{Creating Counter-Narratives Through Southeast Asian-American Stories}

To reiterate, only four of the 151 articles reviewed addressed, in whole or in part, Southeast AsianAmericans. With that being said, outside of the articles under review, there appears to be a growing body of research that seeks to disaggregate data for the pan-Asian-American community. Southeast Asian-Americans, specifically Cambodian, Hmong, Laotian, and Vietnamese, have been at the center of the analysis. The argument has invariably been in favor of data disaggregation, given the disparities in their stories, which are concealed behind the numbers. The Southeast Asian-American label is itself broad and incorporates nearly 10 different subgroups, and efforts have been made to examine specific subgroups. One study that provided a critical literature review of Southeast Asians noted that, of the four subgroups listed above, extant literature has grown with regard to Vietnamese and Hmong communities. Scholars know less about Cambodian and Laotian academic achievement, beyond baseline statistics often referencing the U.S. Census, American Community Survey (ACS).

Studies that focused on specific subgroups attempted to help researchers capture a more nuanced picture of constructed identities and lived experiences. For example, one researcher noted that, "Cambodian American parents and community leaders believe strongly in the link between the Khmer language and Cambodian ethnic identity, arguing that to be Khmer (Cambodian) is to speak Khmer." A study on Vietnamese youth found that how they interpret gender roles impacts how "students define cultural, ethnic, and academic identities." And a study on Hmong leaders

found, "[T]he essentialism of Hmong community leaders may be viewed as the formation of a 'cultural border' in the struggle against school exclusionary practices that undermine the identities and worth of Hmong families."

These studies provide a nuanced examination of the vast cultural and structural differences across Asian-American ethnic subgroups, which often get lost in statistics that aggregate racial data. Studies demonstrated that Southeast Asian-Americans have different stories of migration, culture, and language. These differences are captured in the disaggregation of data.

Another important trend in the literature was the examination of Southeast AsianAmericans in terms of "racialized discourses and ethnic epistemologies." Research has been strongly encouraged to challenge assumptions of a "universal experience within and across groups," specifically examining the notion of intersectionality: the complex interplay of race and how it is shaped by ethnicity, gender, sexuality, power, privilege, and other social markers 
(Delgado \& Stefancic, 2012). This discussion is likely to shift the conversation away from the traditional bifurcation of "ideological whitening" of economically successful East and South Asians and the "ideological blackening" of low-income Southeast Asians (Ong, 1999, see also Stacey Lee, 2006). However, the disaggregation of data for under-represented East and South Asians may also tell a different story, one that does not assume that all East and South Asians are exemplars of academic and financial success. They, too, may also invariably experience social and economic hardships. For example, in interviewing a Sikh/South Asian-American, one study noted that the participant "used to blame [her] ethnicity for all the problems in [her] life ... and part of it was just not learning about [her] community in ... history classes." Thus, more nuanced accounts of Asian-American stories in general may enable researchers "to understand that racism is something that affects all of [our] lives."

\section{Discussion}

\section{Aggregating Data Silences Under-Represented Southeast Asian-Americans}

The main finding was that aggregating racial data for Asian-Americans silences under-represented Southeast Asian-Americans. This was visible in the fact that only four research studies (out of 151) had been published on Southeast Asian-Americans within a 10-year span, in leading K-12 and higher educational peer-reviewed journals, despite the fact that Southeast Asian-Americans have entered the United States en masse decades ago largely fleeing from war, genocide, and political persecution. Many did not enter the United States on special work visas as doctors, lawyers or scientists despite common public (mis)perception. This finding could suggest that the continued fight for racial equality in educational research for Southeast Asian-Americans requires more attention at the most basic (statistical) level. Because Asian-Americans are viewed through a monolithic lens of widespread success and academic excellence, as evidenced in this research, lumping Southeast Asian-Americans under the Asian umbrella conceals the social and economic hardships these people face at school and in the community. Concealing these hardships could deny Southeast Asian-American applicants from under-resourced families from receiving financial aid awards and need-based scholarships, fellowships, and grants they need and deserveand often reserved for applicants from historically under-represented communities but largely denied to them because of their "Asianness." Because they are grouped under the "Asian" label, many Southeast Asian-American applicants may not qualify for competitive need-based financial assistance. Because their hardships are concealed - again as a result of data aggregation, Southeast Asian-Americans must continue to provide evidence and data to disrupt the false narrative of success propelled and perpetuated through the model minority myth. This work to disrupt is at a basic level because these people must exert their energy and resources to conduct research that produces evidence to show that they are also under-served and therefore require the support and resources (too) that is often granted to other historically under-represented groups.

The question then becomes: How can educational researchers fight for racial equality for larger racial minority groups while simultaneously fighting for Southeast Asian-American children, many of whom come from financially under-resourced families and communities? Why does racial equality in education have to be a zero-sum game? Where is the humanity in such a game?

A large majority of the studies in the analysis applied the pan-ethnic Asian-American label in describing different Asian subpopulations. Complex patterns of migration into the United States 
were largely ignored, as well as the historical, political, social, and economic factors that have shaped their lives before and after entering America. Stacey Lee addresses this issue, noting that it "inadvertently support[s] the racist discourse that constructs Asians as a homogenous group, [implying] that Asians are 'all alike' and conform to 'types"” (p. 17, as cited in Lowe, 1996, p. 71).

Some researchers appeared to have ignored the fluidity and dynamism of intersectional identities of Asian-American students marked by social class, ethnicity, gender, and generation (Stacey Lee, 2006). Not significantly, many researchers knowingly or unknowingly reduced these students' experiences into one label (i.e., Asian) or bifurcated categories (i.e., success or failure). The reduction of Asian-American students into arbitrary categories and false dichotomies manufactured an image that perpetuates dangerous myths and stereotypes that further invisibilize and erase these youth.

It could be that researchers were reacting to how the U.S. government handles data pertaining to Asian-Americans. For example, researchers could have viewed Southeast Asians as not requiring attention, because extant federal, state, and district data-which are often not disaggregated by Asian ethnicity_-perpetuates a stereotype that all Asians are academically high performing, a claim substantiated in the study's findings. However, the American historian, Sean P. Harvey, in Ideas of Race in Early America (2016), traced the roots of "race" and argued invariably that racism is the ancestor of race, which has always been a social construction that (inhumanely) categorized and hierarchized Whites and people of color. He argued, "'Race,' as a concept denoting a fundamental division of humanity and usually encompassing cultural as well as physical traits, was crucial in early America. It provided the foundation for the colonization of Native land, the enslavement of American Indians and Africans, and a common identity among socially unequal and ethnically diverse Europeans" (Harvey, 2016, p. 1). Because race is a social construction, and researchers often rely on race as a "quantifiable" variable, then it follows that the same researchers are relying on data that are founded on racist principles. The way in which mainstream researchers use "Asians" as a racial category appears to be a function of how race, as a social construction, is (mis) understood. The CRT framework, which necessarily invokes history, among other factors, into the analysis often enables researchers to better comprehend this point.

Conversely, disaggregated data for Asian-Americans often paint a different picture: one that highlights great disparities concealed behind the numbers especially in K-12 (Teranishi, 2002) and higher education research (Teranishi, 2010). That researchers engage in what I refer to as "the political culture of silencing and erasing" marginalized Southeast Asian-American students from the literature perhaps suggests that a lack of cultural and structural awareness of these communities embraces inequitable, and on some level-racist - tendencies (see Lowe, 1996; Ngo \& Lee, 2007; Stacey Lee, 2006). There is a particular irony in which studies seeking to "narrow achievement gaps" and "erase inequities" for under-represented students appear to further marginalize Southeast Asian-Americans, including other groups such as Native Americans, Pacific Islanders, and Native Hawaiians, to name those few, perhaps because these groups are small and often lack political capital in the United States to warrant stronger attention.

To be clear, the federal U.S. Census data suggest that many under-represented Southeast Asian subgroups have educational and life experiences that often mimic African Americans/Blacks and Hispanics/Latinos, with some of the highest poverty and high school "dropout" rates in the country. Without essentializing Asian-Americans, it ought to be noted that Southeast AsianAmericans need and deserve more attention from researchers, given the hardships and challenges they often face in and out of school. 
In situating this finding through a CRT lens, we could say that researchers should engage in discussions that concurrently address CRT's "voice-of-color thesis" and an explicit examination of the myth as a persistent weapon of racializing, silencing, marginalizing, and erasing AsianAmericans. This CRT thesis holds that because of different histories and experiences with oppression, ethnic minority writers and thinkers may be able to communicate to their counterparts matters that they are unlikely to know. Thus, minority status brings with it a presumed competence to speak about race and racism. While only four studies had emerged within the 10-year span, it appears that many Southeast Asian-American scholars outside of this systematic review are conducting research studies that center the voices and lived experiences of the Southeast AsianAmerican community, which is intended to reject the model minority myth and to disrupt false narratives of success and categorical bifurcations (e.g., Ngo \& Lee, 2007).

\section{Conclusion and Implications for Research, Practice, and Policy}

This research shows that insufficient attention has been placed on Southeast Asian-American issues in leading K-12 and higher educational research. The low publication rate could be symptomatic of many factors including low submission rates from scholars publishing work on this population. Or, it could result from editors and blind reviewers lacking the education and cultural awareness to understand the many and varied political, social, cultural, economic, and migratory factors that shape these people.

Instead of fighting to level the racial playing field for under-resourced Southeast AsianAmericans, many of our scholars must exert their energy and resources to validate the most basic statistical fact that our people hail from under-resourced families and neighborhoods. In other words, what should be understood as a statistical given (i.e., that Southeast Asian-Americans have high poverty rates, struggling to complete or pay for school, and are (still) overcoming intergenerational war trauma), they must work hard to prove their place in a America in which racism is still her original sin.

In closing, we must ask the following questions to achieve racial equality for Southeast Asian-Americans in K-12 and higher educational research: How do aggregated data impact the way educators and school leaders support Southeast Asian-American students, especially if perceptions of "Asians" is one of high educational attainment and achievement as perpetuated by the myth? How can public and private higher educational institutions better support marginalized Asian-American students in accessing resources and opportunities? Similarly, how can private foundations better support low-income Asian-American students in accessing research grants and fellowships based on financial need and merit? Future research should explore these and other important questions, particularly in better understanding the rich political, economic, social, and cultural factors that shape these individuals.

Many Southeast Asian-American students need and deserve more support from adults in varying key decision-making positions across research, practice, and policy to thrive in America. As adults, we must frequently hold ourselves accountable and check our implicit biases to avoid (wrongfully) targeting children from these communities. We can start in better educating ourselves on the fact that not all Asian students are alike. From there, we can authentically work together to achieve racial equality for all students. 


\section{References}

Bell, D. A. (2005). The Derrick Bell reader. New York University Press.

Beattie, G. (2013). Our racist heart?: An exploration of unconscious prejudice in everyday life. Routledge.

Chong, V. (2008). Negotiating with agency: Towards an intersectional understanding of violence and resilience in young Southeast Asian men. Institute for the Study of Societal Issues. Retrieved from: http://www.escholarship.org/uc/item/8563k17q

Chong, V., Um, K., Hahn, M., Pheng, D., Yee, C., and Auerswald, C. (2009). Toward an intersectional understanding of violence and resilience: An exploratory study of young Southeast Asian men in Alameda and Contra Costa County, California, Aggression and Violent Behavior, 14, 461-469.

Chou, R.S. (2015). The myth of the model minority: Asian-Americans facing racism. Paradigm Publishers.

Delgado, R., \& Stefancic, J. (2012). Critical race theory: An introduction. New York University Press.

Finfgeld, D.L. (2003). Metasynthesis: The state of the art-so far. Qualitative Health Research, 13, 893-904.

Harris, F., \& Bensimon, E. M. (2007). The equity scorecard: A collaborative approach to assess and respond to racial/ethnic disparities in student outcomes. New Directions for Student Services, 120, 77-84.

Harvey, S.P. (2016). Ideas of race in early America. Oxford Research Encyclopedia American History. Retrieved from: http://americanhistory.oxfordre.com/view/10.1093/acrefore/9780199329175.001.0001/ac refore-9780199329175-e-262

Ladson-Billings, G. (2000). Racialized discourses and ethnic epistemologies. In N. K. Denzin \& Y. S. Lincoln (Eds.), Handbook of qualitative research (pp. 257-277). Sage.

Ladson-Billings, G. (2011). Race to the top again: Comments on the genealogy of critical race theory. Connecticut Law Review, 43(5), 1439-1458.

Lee, S. [Stacey]. (2006). Additional complexities: social class, ethnicity, generation, and gender in Asian-American student experiences. Race Ethnicity and Education, 9(1), 17-28.

Lee, S. [Sharon]. (2006). Over-represented and de-minoritized: The racialization of AsianAmericans in higher education. InterActions: UCLA Journal of Education and Information Studies, 2 (2). Retrieved from http://escholarship.org/uc/item/4r7161b2

Lowe, L. (1996). Immigrant Acts: on Asian-American cultural politics. Duke University Press.

Miles, M.B., \& Huberman, A.M. (1994). Qualitative data analysis: An expanded sourcebook. Sage.

Ngo, B., \& Lee, S.J. (2007). Complicating the image of model minority success: A review of Southeast Asian-American education. Review of Educational Research, 77(4), 415-453.

Normand, S. T. (1999). Tutorial in biostatistics meta-analysis: Formulating, evaluating, combining, and reporting. Statistics in Medicine, 18(3), 321-359.

Ong, A. (1999). Cultural citizenship as subject making: Immigrants negotiate racial and cultural boundaries in the United States. In R. Torres, L. Miron, \& J. Inda (Eds.), Race, identity, and citizenship: A reader (pp. 262-293). University of California Press.

Poon, O., Squire, D., Kodama, C., Byrd, A., Chan, J., Manzano, L., Furr, S., \& Bishundat, D. (2016). A critical review of the model minority myth in selected literature on Asian- 
Americans and Pacific Islanders in higher education. Review of Educational Research, 86(2), 469-502.

Song, M. (2004). Introduction: Who's at the bottom? Examining claims about racial hierarchy, Ethnic and Racial Studies, 27(6), 859-877.

Tchen, J.K.W., \& Yeats, D. (2014). Yellow Peril! An archive of anti-asian fear. Verso.

Teranishi, R.T. (2002). Asian Pacific Americans and critical race theory: An examination of school racial climate. Equity \& Excellence in Education, 35(2), 144-154.

Teranishi, R.T. (2010). Asians in the ivory tower: Dilemmas of racial inequality in American higher education. Teachers College Press.

Timulak, L. (2007). Identifying core categories of client identified impact of helpful events in psychotherapy: A qualitative metaanalysis. Psychotherapy Research, 17, 305-314.

Timulak, L. (2009). Meta-analysis of qualitative studies: A tool for reviewing qualitative research findings in psychotherapy. Psychotherapy Research, 19(4-5), 591-600.

Tuan, M. (1999). Forever foreigners or honorary whites?: The Asian ethnic experience today. Rutgers University Press.

Warikoo, N., \& Carter, P. (2009). Stratification in academic achievement: A call for a new and improved theory. Review of Educational Research, 79(1), 366-394.

Wu, F. H. (2003). Yellow: Race in America beyond Black and White. Basic Books.

Yang, P.Q. (2010). A theory of Asian immigration to the United States. Journal of AsianAmerican Studies, 13(1), 1-34.

\section{About the Author}

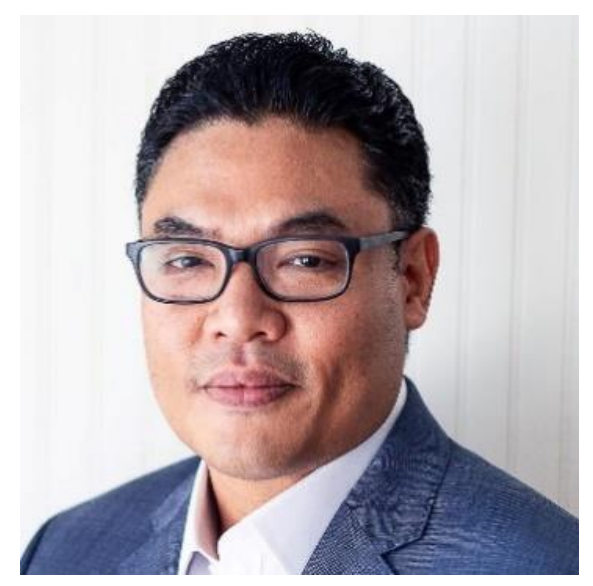

Peter T. Keo, EdD, is is currently Senior Research Fellow at Stanford University's School of Medicine, Center for Compassion and Altruism Research and Education. His research is at the intersection of neuroscience, leadership, and K-12 educational outcomes for vulnerable students. He also conducts research on anti-racism, human rights, and democracy in post-war countries.

Dr. Keo holds a Doctorate in Education from Teachers College, Columbia University, in addition to master's degrees from Harvard University and the University of Chicago. He is certified in "Evaluating Social Programs Using Randomized Controlled Trials" from the Massachusetts Institute of Technology (MIT), through the Poverty Action Lab. He is a regular contributor to the Voice of America - Cambodia, and has provided media commentary for the Education Week, BBC, CSIS-Pacific Forum, The Diplomat, The Phnom Penh Post, The Cambodia Daily, and CCTV, among other outlets. He was appointed by the Governor to serve on the Teachers and Leaders Council in Nevada. His parents are Cambodian refugees.

He has held numerous executive and leadership roles including Senior Adviser (former Cambodian Minister of Education), Secretary-General (Asia Economic Forum), Vice President of Strategy (University of Cambodia), Director (RISE for Boys and Men of Color, University of Pennsylvania), Managing Director \& Chief Strategy Officer (Citizen Schools-Massachusetts), and 
other notable positions. At 23, he was the Assistant Director and Research Fellow of the Cambodian Institute for Cooperation and Peace, an ASEAN think tank to build peace and cooperation. He has also held senior-level academic appointments at UCLA and the University of Pennsylvania. He has served as Principal Investigator on research studies regarding the AsianAmerican community, and has published widely in editorials, books chapters, and peer-reviewed journals including Equity \& Excellence in Education. 

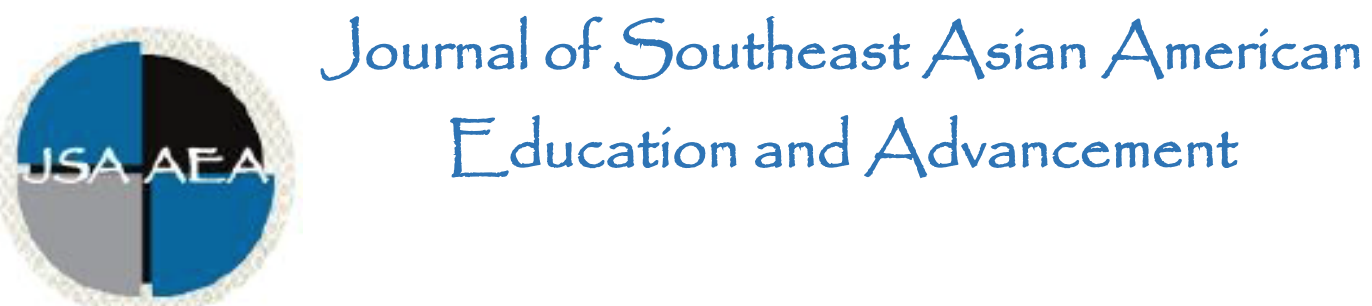

Vol. 15 Iss. 2 Special Issue (2020) $\quad$ www.JSAAEA.org

Special Issue Co-Editors

Dr. Peter T. Keo

Stanford University

Dr. Loan Thi Dao

St. Mary's College of California

\title{
Editor
}

Dr. Wayne E. Wright

Purdue University

Associate Editors

Dr. Chhany Sak-Humphry

University of Hawaii at Manoa

Dr. Phitsamay Sychitkokhong Uy

University of Massachusetts, Lowell

\author{
Book Review Editor \\ Dr. Vichet Chhuon \\ University of Minnesota \\ Creative Works Editor \\ Bryan Thao Worra \\ Lao Assistance Center \\ Journal Manager \\ Fang Gao \\ Purdue University
}

\section{Editorial Review Board}

Dr. Steve Arounsack

California State University, Stanislaus

Dr. Sovicheth Boun

Salem State University
Dr. Carl L. Bankston III

Tulane University

Dr. Phala Chea

Lowell Public Schools 
Dr. Virak Chan

Purdue University

Dr. Loan Dao

St. Mary's College of California

Dr. Changming Duan

University of Missouri-Kansas City

Dr. Sothy Eng

Lehigh University

Dr. Vincent K. Her

University of Wisconsin, Eau Claire

Dr. Peter Nien-Chu Kiang

University of Massachusetts, Boston

Dr. Kevin K. Kumashiro

University of Illinois, Chicago

Dr. Ha Lam

Independent Scholar

Dr. Jonathan H. X. Lee

San Francisco State University

Dr. Monirith Ly

Royal University of Phnom Penh

Dr. Bic Ngo

University of Minnesota

Dr. Leakhena Nou

California State University, Long Beach

Dr. Mark Pfeifer

SUNY Institute of Technology

Dr. Loan T. Phan

University of New Hampshire

Dr. Karen Quintiliani

California State University, Long Beach

Dr. Angela Reyes

Hunter College

The City University of New York

Dr. Fay Shin

California State University, Long Beach

Dr. Christine Su

College of San Mateo

Dr. Alisia Tran

Arizona State University

Dr. Khatharya Um

University of California, Berkeley

Dr. Kim Tran

University of California, Los Angeles, Glendale Community College

Dr. Molly Wiebie

The University of Texas at Austin
Dr. George Chigas

University of Massachusetts, Lowell

Dr. Hien Duc Do

San Jose State University

Dr. Sophal Ear

Occidental College

Dr. Jeremy Hein

University of Wisconsin, Eau Claire

Dr. Nancy H. Hornberger

University of Pennsylvania

Dr. Peter Tan Keo

Stanford University

Dr. Yvonne Kwan

San Jose State University

Dr. Ravy Lao

California State University, Los Angeles

Dr. Stacey Lee

University of Wisconsin, Madison

Dr. Sue Needham

California State University, Dominguez Hills

Dr. Max Niedzwiecki

Daylight Consulting Group

Dr. Clara Park

California State University, Northridge

Dr. Giang Pham

University of Massachusetts Amherst

Dr. Malaphone Phommasa

University of Clifornia Santa Barbara

Dr. Kalyani Rai

University of Wisconsin-Milwaukee

Dr. Cathy J. Schlund-Vials

University of Connecticut, Storrs

Dr. Nancy J. Smith-Hefner

Boston University

Dr. Yer J. Thao

Portland State University

Dr. Monica M. Trieu

Purdue University

Dr. Silvy Un

Saint Paul Public Schools

Dr. Linda Trinh Vo

University of California, Irvine

Dr. Yang Sao Xiong

The University of Wisconsin-Madison

Dr. Zha Blong Xiong

University of Minnesota 


\section{Doctoral Student Editorial Review Board}

Diana Chandara

University of Minnesota-TwinCiteis

Linh Dang

University of Rochester

Annie BichLoan Duong

San Joaquin County Office of Education

Jacqueline Mac

Indiana University

Vanessa Sovanika Na

University of California SanDiego

Khoi Nguyen

George Mason University

Linda Marie Pheng

University of Wisconsin-Madison

Latana Thaviseth

University of California Los Angeles

Melissa Vang

San Diego State University

Soua Xiong

San Diego State University

Claremont Graduate University
Kassandra Chhay

University of Minnesota-Twin Cities

Bao Diep

University of Minnesota-Twin Cities

Nielson Hul

Cornell University

Dung Minh Mao

University of Minnesota-Twin Cities

Hoa Nha Nguyen

Boston College

Thien-Huong Ninh

University of Southern California

Krissyvan Truong

Claremont Graduate University

Mai Vang

University of Massachusetts Boston

Thong Vang

University of Minnesota-Twin Cities 